\title{
Correction to: Epistemic and Political Confrontations Around the Public Policies to Fight COVID-19 Pandemic
}

\section{What can Science Education learn from this episode?}

\author{
Cristiano B. Moura ${ }^{1}$ - Matheus Monteiro Nascimento ${ }^{2} \cdot$ Nathan Willig Lima $^{2}$ \\ Published online: 18 August 2021 \\ ๑) Springer Nature B.V. 2021
}

\section{Correction to: Science \& Education (2021) 30:501-525 \\ https://doi.org/10.1007/s11191-021-00193-3}

The original version of this article unfortunately contained incorrect article title. The corrected article title is presented above.

The original article has been corrected.

Publisher's Note Springer Nature remains neutral with regard to jurisdictional claims in published maps and institutional affiliations.

The original article can be found online at https://doi.org/10.1007/s11191-021-00193-3.

Cristiano B. Moura

cristiano.moura@cefet-rj.br

Matheus Monteiro Nascimento

matheus.monteiro@ufrgs.br

Nathan Willig Lima

nathan.lima@ufrgs.br

1 Centro Federal de Educação Tecnológica Celso Suckow da Fonseca, Graduate Program in Science, Technology and Education, Av. Maracanã, Rio de Janeiro, RJ 229, Brazil

2 Universidade Federal do Rio Grande do Sul, Graduate Program in Physics Education, Av. Bento Gonçalves 9500. Building: 43124, Physics Institute, Campus do Vale, Porto Alegre, RS, Brazil 